\title{
PRAKTIK SOSIAL DALAM PROSES PEMBERDAYAAN MASYARAKAT DI WILAYAH PERI URBAN
}

\author{
Oleh: \\ Siti Nabila *, Nyimas Nadya Izana \\ *Email : snabilaaa2@gmail.com \\ Jurusan Sosiologi Fakultas Ilmu Sosial dan Ilmu Politik \\ Universitas Brawijaya
}

\begin{abstract}
ABSTRAK
Pemberdayaan masyarakat merupakan proses pembangunan dimana masyarakat dilibatkan secara langsung untuk melakukan proses kegiatan sosial untuk memperbaiki situasi dan kondisi masyarakat itu sendiri. Pemberdayaan masyarakat saat ini banyak dikaitkan oleh masyarakat desa dengan tujuan untuk membangun pola pikir serta kompetensi masyarakat desa agar dapat berkembang secara mandiri dalam memenuhi kebutuhan hidup mereka. Adanya pemberdayaan masyarakat di suatu daerah dapat disebabkan karena beberapa kondisi seperti yang terjadi di Kampung Cempluk yaitu kondisi pemuda karang taruna yang tidak produktif serta ikatan solidaritas masyarakat yang kurang terjalin kemudian mendorong para agen untuk memberdayakan masyarakat. Pada proses pemberdayaan, para agen menjadikan seni sebagai sarana dalam pemberdayaan masyarakat. Penelitian ini menggunakan metode penelitian kualitatif dengan pendekatan deskriptif. Hasil temuan dilapangan disajikan dalam bentuk narasi didukung dengan menggunakan data primer dan data sekunder yang telah diperoleh. Hasil penelitian menunjukkan bahwa praktik sosial dalam proses pemberdayaan masyarakat tidak terlepas dari upaya yang dilakukan oleh expert agent serta lay agent dalam menggerakan partisipasi masyarakat. Praktik sosial berbentuk skema institusi S-DL (Signifikasi-Dominasi-Legitimasi). Signifikasi yang dibangun berupa wacana-wacana yang disebarkan oleh agen, dominasi yaitu berkaitan dengan kemampuan agen untuk mempengaruhi masyarakat kemudian legitimasi yaitu adanya pengakuan dari perangkat desa setempat mengenai kegiatan pemberdayaan di Kampung Cempluk.
\end{abstract}

Kata Kunci : Motivasi Tindakan, Monitoring Refleksif, Praktik Sosial 
MIMBAR

JURNAL PENELITIAN SOSIAL DAN POLITIK

\section{A. Pendahuluan}

Kampung merupakan suatu permukiman yang tidak hanya ditemukan di wilayah pedesaan namun juga terdapat di wilayah perkotaan. Menurut (Heryati, 2008) keberadaan kampung di wilayah perkotaan dapat menjadi penunjang pembangunan kota melalui pengembangan ruang kreatif pada kampung itu sendiri kemudian kampung memiliki identitas dan ciri khas sebagai suatu tempat yang mandiri dan dapat berkembang. Sehingga kampung di wilayah perkotaan tidak selalu diartikan sebagai wilayah yang terpinggirkan namun kampung dapat dipandang sebagai sebuah tempat yang memiliki beragam potensi untuk dapat dikembangkan seperti potensi dalam hal kesenian daerah.

Hal tersebut terjadi pada salah satu kampung yang berada di Kecamatan Dau Kabupaten Malang yaitu Kampung Cempluk. Sebutan Kampung Cempluk berawal dari penggunaan cempluk (lampu minyak bersumbu) untuk penerangan karena aliran listrik mulai masuk ke kampung ini sekitar tahun 1992 (Saffnah, 2013).

Secara administratif Kampung Cempluk masuk dalam RW 2 Dusun Sumberejo Desa Kalisongo Kecamatan Dau. Secara geografis Kampung Cempluk merupakan daerah yang berdekatan dengan Kota Malang karena berbatasan dengan Kelurahan Bandulan Kota Malang. Dikarenakan letaknya yang berdekatan dengan Kota Malang sehingga banyak warga Kampung Cempluk yang bekerja dan menempuh pendidikan di Kota Malang. Dalam hal ini, Kampung Cempluk dapat dikategorikan sebagai wilayah periurban karena letaknya yang berdekatan dengan Kota Malang sehingga lambat laun memunculkan transformasi fisik dan sosial di wilayah Kampung Cempluk. Suasana kekotaan semakin terlihat karena asosiasi secara spasial dengan wilayah perkotaan selalu dilakukan oleh warganya. Sehingga wilayah ini terletak antara wilayah kekotaan serta wilayah kedesaan.

Pada awalnya Kampung Cempluk tidak berbeda dengan kampung lainnya yaitu memiliki potensi agraris dan sebagian besar masyarakat berprofesi sebagai petani yaitu petani palawija dan bengkoang. Namun terjadi alih fungsi lahan yaitu lahan pertanian berubah fungsi menjadi kawasan perumahan elite yang saat ini menjadi kawasan perumahan Dieng. Akibat adanya alih fungsi tersebut berdampak pada pada profesi warga Kampung Cempluk dimana mereka harus beralih profesi dari petani menjadi buruh bangunan dan buruh pabrik.

Terjadinya alih fungsi lahan di Kampung Cempluk secara langsung merenggut potensi agraris yang dimiliki kampung. Hal tersebut yang menuntut warganya untuk mencari pekerjaan demi mempertahankan kehidupan mereka. Selain, hilangnya potensi agraris terdapat permasalahan lain yang terjadi yaitu kondisi warganya yang individualis dan kurang menyatu karena disibukkan dengan pekerjaan mereka masing-masing sehingga intensitas untuk berkumpul antar warga kurang. Kemudian para pemuda di Kampung Cempluk juga tidak produktif, karang taruna Dusun Sumberejo hanya aktif berkegiatan ketika hari kemerdekaan RI saja selebihnya mereka sibuk dengan pekerjaan masing-masing. Melihat dari beberapa kondisi yang dialami Kampung Cempluk, menjadi motif utama bagi beberapa tokoh untuk mencetuskan kegiatan pemberdayaan dengan melibatkan partisipasi warga Kampung Cempluk.

Pemberdayaan masyarakat dilakukan oleh Bapak Redy Eko Prastyo bersama dengan pihak lain yaitu sesepuh kampung, ketua RT dan ketua RW. Mereka saling bekerja sama dalam memberdayakan masyarakat yang melibatkan dua RW yaitu RW 1 dan RW 2 Dusun Sumberejo Desa Kalisongo.

Strategi pemberdayaan yang dilakukan di Kampung Cempluk yaitu dengan mengenalkan kesenian kepada warga. Kesenian yang dikenalkan berupa kesenian tradisional maupun modern dari berbagai wilayah di Indonesia seperti kesenian angklung, kesenian musik kulintang, musik perkusi hingga berbagai seni tari juga dikenalkan kepada warga Kampung Cempluk.

Sebelumnya kesenian telah ada di Kampung Cempluk seperti kesenian barongsai, kesenian teater bernama andeande lumut namun seni tersebut hanya dilakukan oleh sekelompok warga tertentu saja belum melibatkan seluruh warga. Sehingga hal tersebut mendorong agen untuk mencetuskan pemberdayaan yang melibatkan partisipasi masyarakat 
MIMBAR

JURNAL PENELITIAN SOSIAL DAN POLITIK

Juni $2019 \quad$ ISSN : 2252-5270 \& E-ISSN : 2620-6056

Volume 8 No. 1

keseluruhan.

Kesenian yang dikembangkan seperti musik angklung, musik kulintang. Seni tersebut. Kesenian tersebut tidak hanya dikenalkan namun warga juga terlibat secara langsung dalam berbagai aktivitas seni seperti latihan atau tampil pada berbagai acara pementasan seni.

Tak hanya dilibatkan dalam kelompok seni, warga Kampung Cempluk juga ikut berpartisipasi dalam kepanitiaan Kampung Cempluk Festival (KCF) khususnya bagi pemuda karang taruna agar mereka dapat memiliki kegiatan yang produktif kemudian warga lainnya juga terlibat dalam menyiapkan keperluan acara KCF. Adanya kegiatan pemberdayaan ini lambat laun memunculkan kesadaran warga Kampung Cempluk untuk mau terlibat dalam kegiatan seni demi memajukan kampungnya.

Pemberdayaan yang dilakukan oleh para tokoh di Kampung Cempluk bertujuan untuk menjadikan kampung sebagai ruang-ruang budaya dan sebagai ruang untuk mengekspresikan kreativitas yang dimiliki warga karena seni tidak hanya ditampilkan pada gedung kampus atau gedung seni namun kampung dapat menjadi ruang untuk melestarikan seni dan budaya dengan melibatkan partisipasi warga setempat.

Adanya pemberdayaan seni di Kampung Cempluk memunculkan suatu perubahan pada kampung itu sendiri dimana Kampung Cempluk menjadi terkenal melalui sorotan media sebagai kampung yang melekat dengan seni dan budaya serta antusiasme yang tinggi dari berbagai komunitas seni di Kota Malang untuk tampil pada acara KCF. Hal tersebut tentunya menjadi kebanggaan tersendiri bagi Kampung Cempluk. Seiring berjalannya waktu dapat menghilangkan stigma tentang kampung bahwa kampung tidak selalu diartikan sebagai suatu tempat hunian dari sekumpulan orang atau keluarga dengan segala keterbatasan, tertinggal, kumuh, kolot dan terpencil namun kampung dapat menjadi suatu elemen penting dalam pembangunan jika masyarakatnya mampu mengembangkan potensi yang ada seperti halnya di Kampung Cempluk.

Pemberdayaan masyarakat merupakan upaya untuk memampukan serta memandirikan masyarakat. Dengan kata lain adalah bagaimana menolong masyarakat untuk mampu menolong dirinya sendiri. Pemberdayaan masyarakat bersifat people centered, participatory, empowering, sustainable (Mardikanto \& Soebianto, 2015:49). Dalam konteks penelitian ini, proses pemberdayaan masyarakat dilakukan dengan melibatkan partisipasi masyarakat dalam kegiatan seni. Sehingga kesenian menjadi sarana untuk memberdayakan masyarakat(Nabila, 2019:30). Kesenian dalam hal ini diwujudkan dalam bentuk seni musik, seni tari atau seni teater. Pada proses pemberdayaan, partisipasi warga dilibatkan secara langsung dalam berbagai kegiatan seni seperti pelatihan seni dan festival karya seni.

Menurut Giddens (2010) praktik sosial merupakan tindakan sosial yang dilakukan berulang dan terpola dalam ruang dan waktu. Praktik sosial dalam proses pemberdayaan ini yaitu ketika agen dan warga saling bertemu dalam aktivitas seni yang dilakukan. Pertemuan serta aktivitas seni yang dilakukan masyarakat telah terpola dalam kurun waktu tertentu sehingga lambat laun menjadi rutinitas atau kebiasaan bagi mereka yang tidak perlu dipertanyakan kembali mengapa mereka melakukan tindakan tersebut(Nabila, 2019:30).

\section{B. Metode Penelitian}

Lokasi penelitian dilakukan di Kampung Cempluk, Dusun Sumberejo Kabupaten Malang. Dalam penelitian ini, penulis menggunakan pendekatan deskriptif dengan metode kualitatif. Sugiyono, (2016:17) mengungkapkan bahwa: Metode kualitatif dengan jenis deskriptif yang digunakan pada penelitian ini untuk menjelaskan dan mendeskripsikan proses, kondisi sosial atau fenomena melalui penjabaran kata berupa narasi. Kemudian hasil pemahaman atas fenomena tersebut diuraikan dalam bentuk kata-kata dan bahasa untuk menjadi data penelitian lalu dinarasikan secara deskriptif sehingga pembaca mampu memahami peristiwa tersebut.

Dalam metode penelitian deskriptif kualitatif tidak dikenal adanya sampel, melainkan informan. Hal ini dibutuhkan untuk mendapatkan informasi yang lebih jelas mengenai masalah penelitian yang dibahas. Dalam hal ini penulis menggunakan metode snowball sampling. Oleh karena itu, informan yang dipilih pada penelitian ini 
MIMBAR

JURNAL PENELITIAN SOSIAL DAN POLITIK

Juni 2019

adalah sebagai berikut:

Tabel 1. Karakteristik Informan

\begin{tabular}{lll}
\hline No & Informan & Jumlah \\
\hline 1. & $\begin{array}{l}\text { Praktisi } \\
\text { Pemberdayaan }\end{array}$ & 3 \\
2. & $\begin{array}{l}\text { Anggota Karang } \\
\text { Taruna }\end{array}$ & 3 \\
& &
\end{tabular}

$\begin{array}{lll}\text { 3. Warga } & 2 \\ & \text { Jumlah } & 8 \text { Orang }\end{array}$

Sumber: diolah peneliti, 2019

Teknik analisis data yang digunakan pada penelitian ini yaitu teknik analisis data model Miles dan Huberman dalam (Sugiyono, 2016:246-252). Meliputi kondensasi kata (penyempurnaan data) data, penyajian data bentuk uraian, bagan atau tabel kemudian setelah data disajikan dan dideskripsikan maka dapat dibuat kesimpulan baru (verifikasi data).

\section{Hasil Penelitian dan Pembahasan \\ 1. Motif Agen dalam Melakukan \\ Pemberdayaan}

Munculnya pemberdayaan di Kampung tidak terlepas dari kondisi Kampung Cempluk itu sendiri. Kondisi yang terjadi yaitu ikatan solidaritas warga yang kurang terjalin karena mereka disibukkan pekerjaan masing-masing sehingga intensitas pertemuan antar warga sangat minim. Selain itu kondisi para pemuda karang taruna yang tidak aktif karena banyaknya pemuda yang memilih bekerja di luar kampung sehingga mengabaikan kondisi kampungnya (Nabila,2019:60-61). Beberapa kondisi tersebut menjadi motif bagi agen yaitu Bapak Redy untuk memunculkan pemberdayaan masyarakat sebagai wadah untuk menguatkan kembali solidaritas warga serta untuk mengembangkan potensi Kampung Cempluk.

Dalam proses melibatkan masyarakat, Bapak Redy selaku expert agent terlebih dahulu mengajak Mas Hanafi yang merupakan Ketua Karang Taruna Dusun Sumberejo untuk bekerja sama menggerakkan masyarakat dalam kegiatan pemberdayaan. Mas Hanafi teridentifikasi sebagai lay agent karena ia mendukung tindakan yang dilakukan expert agent.

\section{Upaya Agen dalam Memberdayakan} Masyarakat

Pada proses pemberdayaan, agen menjadikan kesenian sebagai sarana untuk memberdayakan masyarakat. Kesenian dalam hal ini yaitu berupa seni musik seperti angklung, kulintang dan seni tari.

Agen berupaya mengenalkan dan mengajarkan kesenian tersebut kepada warga. Kemudian warga dilibatkan pula dalam kelompok-kelompok seni terbentuk seperti kelompok seni Angklung Kirana yang diikuti ibu-ibu, kelompok musik etnik yaitu Mugisae yang diikuti para pemuda dan kelompok musik kulintang yang bernama D’nting Candra Kinanti (Nabila, 2019:7177). Biasanya warga mengikuti latihan seni ketika malam hari karena waktu mereka lebih luang dibandingkan di siang hari yang mana mayoritas warga bekerja.

Tak hanya orang dewasa saja yang dilatih seni, anak-anak juga diajari menari ketika mereka libur sekolah. Dibentuknya kelompok-kelompok seni bertujuan untuk menyatukan warga sehingga ikatan solidaritas warga terjalin antar warga semakin kuat serta untuk menciptakan lingkungan produktif bagi warga.

Selain warga berpartisipasi pada kelompok-kelompok seni. Warga juga berpartisipasi dalam Kampung Cempluk Festival (KCF) yang dilaksanakan pada Bulan September setiap tahun.

KCF tidak hanya melibatkan warga kampung namun turut serta melibatkan berbagai komunitas seni yang ada di Malang sebagai pengisi acara. Biasanya pelaksanaan KCF dilaksanakan selama lima hari berturutturut dengan jumlah pengisi acara sekitar 60 komunitas seni yang ada di Malang Raya. Tujuan diadakannya KCF yaitu untuk menghidupkan kembali kampung dengan seni dan budaya karena kampung pada dasarnya merupakan ruang dari ketahanan budaya yang paling mendasar dari sebuah Negara (Nabila, 2019:77-82).

Dalam kegiatan pemberdayaan, agen selalu melibatkan partisipasi warga secara konsisten. Sehingga lambat laun memunculkan perubahan pada warga Kampung Cempluk. Mereka menjadi tidak 
MIMBAR

JURNAL PENELITIAN SOSIAL DAN POLITIK

Juni 2019 ISSN : 2252-5270 \& E-ISSN : 2620-6056

awam dengan kesenian. Kegiatan-kegiatan seni yang mereka lakukan berulang dan terpola pada ruang dan kurun waktu tertentu telah menjadi rutinitas mereka yang tidak perlu dipertanyakan kembali. Tindakan tersebut yang disebut Giddens sebagai praktik sosial.

Pada kegiatan pemberdayaan, agen melakukan monitoring refleksif tindakan dimana agen tidak hanya memonitor tindakannya dan tindakan orang lain agar melakukan seperti apa yang diinginkan agen (Giddens, 2010:58). Namun agen juga memonitor aspek-aspek lain dalam proses pemberdayaan yaitu seperti perkembangan dan konsistensi warga dalam berlatih seni, kebutuhan-kebutuhan yang diperlukan dalam pelaksanaan KCF seperti dana, konsumsi, publikasi. Hal-hal tersebut juga dikontrol agen agar tidak terjadi suatu hal di luar kendali agen.

\section{Dimensi Kesadaran Agen dan Masyarakat}

Dalam menjalankan praktik sosial agen dan memiliki tingkat kesadaran yang mempengaruhi mereka bertindak. Bapak Redy selaku expert agent dan Mas Hanafi selaku lay agent dalam konteks penelitian ini memiliki kesadaran diskursif karena secara pemikiran ia lebih tertata jelas terkait tujuan serta konsep pemberdayaan masyarakat di kampung dan memiliki rencana yang tersusun rapi(Nabila, 2019:8586). Kemudian ia mampu merefleksikan dan dapat memberikan penjelasan kepada warga mengenai tujuan yang akan dicapai dengan adanya pemberdayaan.

Sedangkan kesadaran yang dimiliki warga yaitu terdapat beberapa warga yang memiliki motivasi tidak sadar. Artinya motif yang aktor sendiri sebenarnya tidak mengharapkan hasil tersebut, mereka hanya melakukan tindakan yang diwajibkan oleh lingkungannya seperti halnya terdapat beberapa orang yang keterlibatan mereka dalam kelompok seni hanya sekedar ikutikutan. Namun disisi lain, mayoritas warga telah menganggap kegiatan seni menjadi bagian dari rutinitas mereka yang tidak perlu dipertanyakan kembali sehingga dalam hal ini mereka memiliki kesadaran praktis (Nabila, 2019:87-88).

\section{Skema S-D-L dalam Praktik Sosial} Pemberdayaan Masyarakat

Praktik sosial dalam proses pemberdayaan masyarakat di Kampung Cempluk tidak terlepas dari tiga prinsip struktural menurut Giddens karena dalam praktik sosial tersebut struktur signifikasi, struktur dominasi dan struktur legitimasi saling berkaitan dalam membentuk praktik sosial tersebut.

Struktur signifikasi berkaitan dengan wacana yang dibangun oleh agen dalam proses pemberdayaan masyarakat. Kemudian struktur dominasi dalam penelitian ini dilihat dari dua hal yaitu secara otoritatif (penguasaan orang) dan alokatif (penguasaan barang/ekonomi) yang terjadi dalam proses pemberdayaan kemudian struktur legitimasi yang berupa pengakuan atau aturan normatif.

Praktik sosial terbentuk dengan adanya struktur signifikasi berupa wacana bahwa pemuda harus punya rasa memiliki kepada kampung Mereka (Nabila, 2019:91-92). Hal itu kemudian menjadi motivasi bagi pemuda untuk menjadi penggerak warga lainnya supaya mau berpartisipasi pada kegiatan seni yang ada.

Struktur dominasi dilihat dari dua hal yaitu secara otoritatif (penguasaan terhadap orang lain) yaitu ketika expert egent dan lay agent yang memiliki kemampuan dalam bidang seni yang kemudian mengajarkan dan mengajak warga berlatih seni kemudian secara alokatif (penguasaan terhadap barang) yaitu adanya pihak sponsor yang menjadi penyokong dana dalam kegiatan tersebut. Sehingga pihak sponsor melakukan dominasi secara alokatif dalam kegiatan pemberdayaan tersebut berdasarkan Memorandum of Understanding (MoU) yang telah disepakati (Nabila, 2019:93). Biasanya dalam $M o U$ tersebut terdapat hak bagi sponsor untuk membuat spanduk atau poster yang mempromosikan produknya dan dipasang selama berlangsungnya acara KCF.

Struktur signifikasi dan dominasi tersebut didukung dengan adanya legitimasi dari perangkat desa setempat berupa persetujuan untuk melakukan kegiatan seni di kampung, perangkat desa juga sangat mendukung adanya kelompok seni dan terselenggaranya $\mathrm{KCF}$ setiap tahun karena kegiatan tersebut dapat menjadikan Kampung Cempluk memiliki kekhasan 
MIMBAR

JURNAL PENELITIAN SOSIAL DAN POLITIK

Juni 2019 ISSN : 2252-5270 \& E-ISSN : 2620-6056

Volume 8 No. 1

dengan kesenian serta membuat Kampung

Cempluk semakin terkenal di Kota Malang

(Nabila, 2019:93-94).

Tabel 2. Pola Hubungan S-D-L

\begin{tabular}{|c|c|c|c|}
\hline & $\bar{S}$ & D & $\mathbf{L}$ \\
\hline Struktur & $\begin{array}{l}\text { Adanya } \\
\text { wacana yang } \\
\text { dibangun } \\
\text { untuk } \\
\text { memberikan } \\
\text { pemahaman } \\
\text { kepada warga }\end{array}$ & $\begin{array}{l}\text { Peningkata } \\
\mathrm{n} \\
\text { kemampua } \\
\mathrm{n} \text { warga } \\
\text { melalui } \\
\text { latihan seni }\end{array}$ & $\begin{array}{l}\text { Persetujuan } \\
\text { dari } \\
\text { perangkat } \\
\text { desa } \\
\text { terhadap } \\
\text { kegiatan seni }\end{array}$ \\
\hline Sarana & $\begin{array}{l}\text { Adanya } \\
\text { kelompok seni } \\
\text { dan Kampung } \\
\text { Cempluk } \\
\text { Festival } \\
(\mathrm{KCF})\end{array}$ & $\begin{array}{l}\text { Adanya } \\
\text { struktur } \\
\text { kepanitiaa } \\
\text { n, } \\
\text { pelatihan } \\
\text { seni, } \\
\text { adanya } \\
\text { sponsor }\end{array}$ & $\begin{array}{l}\text { Adanya } \\
\text { dukungan } \\
\text { dan bantuan } \\
\text { dari } \\
\text { perangkat } \\
\text { desa }\end{array}$ \\
\hline Interaksi & $\begin{array}{l}\text { Diskusi } \\
\text { tentang seni, } \\
\text { rapat }\end{array}$ & $\begin{array}{l}\text { Melalui } \\
\text { rapat-rapat } \\
\text { rutin } \mathrm{KCF}\end{array}$ & $\begin{array}{l}\text { Adanya } \\
\text { aturan serta } \\
\text { pengakuan } \\
\text { tidak tertulis }\end{array}$ \\
\hline
\end{tabular}

Sumber: diolah peneliti, 2019

\section{Penutup}

Berdasarkan uraian diatas, maka dapat disimpulkan berupa hasil penelitian sebagai berikut:

a. Motif yang menjadi latar belakang agen dalam melakukan pemberdayaan masyarakat di Kampung Cempluk yaitu kondisi warga Kampung Cempluk yang semakin individualis karena mereka disibukkan dengan pekerjaan masingmasing. Tak hanya itu, banyaknya pemuda Kampung Cempluk yang memilih bekerja di kota sehingga banyak yang meninggalkan kampung serta pasif terlibat pada kegiatan yang ada di kampung. Hal tersebut tentunya berdampak pada hilangnya rasa peduli untuk memajukan Kampung Cempluk karena mereka beranggapan bahwa bekerja di kota lebih menjanjikan dibandingkan hanya bekerja serabutan di kampung. Beberapa kondisi tersebut mendorong expert agent dan lay agent untuk melakukan pemberdayaan masyarakat.

b. Dalam proses pemberdayaan yang dilakukan menjadikan kesenian sebagai sarana untuk memberdayakan warga. Warga dilibatkan secara langsung dalam berbagai kegiatan seni seperti kelompokkelompok seni. Para pemuda karang taruna juga dilibatkan menjadi panitia Kampung Cempluk Festival (KCF) yang diselenggarakan setiap tahun.

c. Aktivitas seni yang dilakukan para warga secara terus menerus kemudian membentuk praktik sosial dalam proses pemberdayaan. Para warga sudah tidak awam lagi kesenian namun mereka semakin terbuka untuk berlatih seni karena seni telah dianggap menjadi bagian penting dari Kampung Cempluk.

d. Praktik sosial pemberdayaan seni di Kampung Cempluk terbangun dengan bentuk institusi S-D-L (Signifikasi, Dominasi, Legitimasi). Struktur signifikasi yaitu adanya wacana bahwa pemuda harus punya rasa memiliki kepada kampung mereka. Struktur dominasi dilihat dari dua hal yaitu secara otoritatif (penguasaan terhadap orang lain) seni yang kemudian (penguasaan terhadap barang) Struktur signifikasi dan dominasi tersebut didukung dengan adanya legitimasi dari perangkat desa setempat berupa persetujuan untuk melakukan kegiatan seni di kampung, perangkat desa juga sangat mendukung adanya kelompok seni dan terselenggaranya KCF setiap tahun karena kegiatan tersebut dapat menjadikan Kampung Cempluk memiliki kekhasan dengan kesenian.

\section{DAFTAR PUSTAKA}

Giddens, A. (2010). Teori Strukturasi. Yogyakarta: Pustaka Pelajar.

Heryati. (2008). Kampung Kota sebagai bagian dari Permukiman Kota Studi Kasus: Tipologi Permukiman Rw 01 Rt 02 Kelurahan Limba B dan Rw 04 Rt 04 Kel. Biawu Kecamatan Kota Selatan Kota Gorontalo. Jurnal Universitas Negeri Gorontalo, 11-13.

Mardikanto, \& Soebianto. (2015). Pemberdayaan Masyarakat dalam Perspektif Kebijakan Publik. 


\section{MIMBAR}

JURNAL PENELITIAN SOSIAL DAN POLITIK

Bandung: Alphabeta.

Nabila, S. (2019). Praktik Sosial dalam

Proses Pemberdayaan Masyarakat di Kampung Cempluk Dusun Sumberejo Desa Kalisongo Kabupaten Malang. Malang: Universitas Brawijaya.

Priyono, H. (2002). Anthoniy Giddens: Suatu Pengantar (Gramedia, Ed.). Jakarta.

Saffnah. (2013). Kampung Cempluk Festival. Retrieved April 6, 2018, from September website: http://www.kampungcempluk.com/do c-beritamelihat-aktivitas-berkesenianwarga-kampung-cempluk-1/

Sugiyono. (2016). Memahami Penelitian Kualitatif. Bandung: Alfabeta. 